Article

\title{
Bringing Back in the Spatial Dimension in the Assessment of Cultural and Creative Industries and Its Relationship with a City's Sustainability: The Case of Milan
}

\author{
Aura Bertoni, Paola Dubini * and Alberto Monti (D) \\ ASK Research Center, Bocconi University, 20136 Milan, Italy; aura.bertoni@unibocconi.it (A.B.); \\ amonti.man@unibocconi.it (A.M.) \\ * Correspondence: paola.dubini@unibocconi.it
}

Citation: Bertoni, A.; Dubini, P.;

Monti, A. Bringing Back in the Spatial

Dimension in the Assessment of

Cultural and Creative Industries and Its Relationship with a City's Sustainability: The Case of Milan. Sustainability 2021, 13, 10878. https:/ / doi.org/10.3390/su131910878

Academic Editor: Tomonobu Senjyu

Received: 2 July 2021

Accepted: 16 September 2021

Published: 30 September 2021

Publisher's Note: MDPI stays neutral with regard to jurisdictional claims in published maps and institutional affiliations.

Copyright: (C) 2021 by the authors Licensee MDPI, Basel, Switzerland. This article is an open access article distributed under the terms and conditions of the Creative Commons Attribution (CC BY) license (https:// creativecommons.org/licenses/by/ $4.0 /)$.
Abstract: The Cultural and Creative Cities Monitor (CCCM) is a valuable tool to measure and compare European cities' cultural and creative vitality. It addresses three dimensions: the presence of cultural venues and facilities (i.e., Cultural Vibrancy); the jobs and innovations connected to the so-called creative industries (i.e., the Creative Economy); and the enabling conditions for culture and creativity diffusion: human capital, diversity, trust and openness, international accessibility, and connectivity (i.e., an Enabling Environment). Comparing and ranking cities on these different dimensions offer policymakers the possibility of developing strategies related to their development (Montalto et al. 2019). However, as is recognized in the report presenting the CCCM, significant methodological limitations exist. They are related to both the tool and the potential behavioral implications it generates (JRC-OECD Handbook, 2008) and to the difficulties with addressing a multifaceted phenomenon with scant data, which offer limited opportunities to adequately measure cultural and creative cities (Van Puyenbroeck et al. 2021). In this paper, we integrate the CCCM framework to propose a spatially contextualized application at the city level as a tool to support policymakers' understanding of the potential role of cultural and creative organizations in city development (Soini and Dessein, 2016). We, therefore, build our arguments on a recent stream of research showing the importance of the spatial dimension to understand the relevance of cultural and creative industries within a context and inform decision-makers (Boal-San Miguel and Herrero-Prieto, 2020). This spatial dimension is even more important at the city level, where public, private, and non-profit organizations interact to execute culture-led policies (Bonet and Négrier, 2018). In this case, the location of specific organizations may be critical in offering opportunities at the neighborhood level, paving the way to space-driven local level policies (e.g., the $15 \mathrm{~min}$ walking strategy; see e.g., Pisano, 2020).

Keywords: cultural and creative cities; neighborhood; cultural policies; 15 -minute city; cultural and creative cities monitor; composite indicator(s)

\section{Defining and Measuring CCI}

In the last 20 years, culture and creativity have progressively earned a relevant role in national and supranational institutional discourse and public and academic debates. Several contributions acknowledge the complexity of defining and conceptualizing Cultural and Creative Industries (CCIs) [1-13]. Other authors focus on defining the context for CCIs and their spatial agglomeration [9-17] and on measuring outcomes with different approaches (see for a review and empirical tests [18-24].

CCIs have been viewed as drivers of economic growth [25-31]. Beyond their intrinsic value and direct economic impact, culture and creativity have been considered a source of innovation [32-35] and social impact through wellbeing [36-38], inclusion [39,40] (see [41] for a critic urban regeneration [42-45]; see [46] for a critical account), and sustainability [47-50]. This evidence underlines and explains both the political interest in the creative 
economy at all levels [51-53] and the potential for culture-led policy [10,54]. At the same time, the literature acknowledges the ambiguity of the concept [6], the lack of specific and granular data to observe the phenomenon [55], the systemic nature of the benefits created, and, therefore, the difficulty with making individual organizations accountable [56] and monitoring policies' effectiveness [10].

Of particular interest for this paper is the attention given to the contribution of CCIs to contemporary cities' and regions' development, visibility, and attractiveness [57] (see $[14,31,58,59]$ for a review on cities), even though other aggregations at the territorial level have been widely analyzed, such as cultural clusters and districts $[9,11,16,17,35,60,61]$.

In this work, we focus on the importance of CCIs at the city level for several reasons. First, cities have historically been the center stage in which culture and creativity have been produced, consumed, and attracted (as in the case of the Renaissance in Italy [21,62]). Second, in 2020, 56.2 percent of the world's population was urban [63], with the highest concentration of residents living in cities in Northern American countries (84\% compared with Europe, around 75\%). Additionally, more than $80 \%$ of the world's GDP comes from cities [64]. Moreover, local governments have significant autonomy and power to affect citizens' wellbeing and opportunities [41,65]. This autonomy is even more critical today, especially concerning resource allocation for social policies and the management of services [44] given the reduction of public expenditure in culture within the EU28 [66] due to the economic crisis [67]. As a consequence, this situation has pushed for a revision of governance models in the cultural sector, paving the way to public-private partnerships that are best analyzed at the city level [68-70]. Finally, positive externalities [31,71] but also the potential downsides (even though they remain less explored) related to creativity [41,51] have been analyzed mainly at the city level. While the clustering of CCIs around citiesparticularly global ones-has been explored [58], growing attention is being paid to more peripheral/smaller cities and areas [58] (see for exceptions [14,15,55,70]).

However, in the growing literature stream that analyzes global capital cities and regions [58], Italy is relatively less studied. One of the most recent and complete studies on CCIs at the territorial spatial level in Europe did not account for Italy [72], and Italy was also left out of the chapter on cities and sustainability presented in the World Happiness Report 2020 [38]. Part of the reason for this is the smaller average size of Italian cities compared with their European and international counterparts [73], making them a difficult reference in international comparative studies. Studies of Italian CCIs and their geographical distribution (starting from the seminal work of Santagata [11] explore: their relative concentration in specific cultural industries $[74,75]$ specialization choices and agglomeration effects at the local level $[9,11,14,15,70]$ and the role of culture-led policies for local and regional development (e.g., [61]). Finally, social capital [76], driven by traditions and social structures, together with a diffused, protected, and specific heritage [77], is embedded in culture-driven local development discourses [78,79].

As suggested by Lazzaretti, Capone, and Secilmis [80], only a few studies-such as DCMS [1] - follow standardized metrics in the definition of CCIs and assess their performances and outcomes in the areas in which they are located. Additionally, most of the available research refers to the national level (see for a similar analysis [55]). Finally, the non-coordinated variety of measurement tools and approaches [81] does not favor evidence-based policy $[56,72,82,83]$ Available data for comparative analysis either focus on a very limited set of indicators (such as Eurostat data) or take a small geographical area as a reference [84].

The Cultural and Creative Cities Monitor (CCCM) is a valuable instrument to measure and compare European cities' cultural and creative vitality [56,85]. It allows for the comparison and ranking of cities, including Italian ones, on different dimensions, making it possible for policymakers to develop strategies related to their development [56]. However, critical methodological limitations still exist, related both to the tool and the potential behavioral implications it generates [86].). Taking the city as a unit of analysis for urban policy purposes may be misleading, as it considers cities to be homogeneous 
within their boundaries. Quite to the contrary, there is ample evidence of differences in city texture at the neighborhood level, often explaining or leading to those social and economic inequalities that urban policies aim to address [41].

Notwithstanding the city level index's significant conceptual and methodological contribution [56,85], there is, therefore, evidence that such an index may not be detailed enough to support urban level policies. More specifically, social and environmental pressures and the aftermath of COVID-19 show that the notion of space and the habits of citizens are changing, and so are many local agendas. One vision currently heavily debated at the municipality level is based on the Ville du quart d'heure approach, also known as the 15-Minute City (i.e., FMC). The FMC is a neighborhood-unit-intended solution [87] inspired and developed by the French-Colombian urban scientist Carlos Moreno and implemented and championed by the mayor of Paris Anne Hidalgo [88]. It is based on and provides a unified vision of various strategies employed in several metropolitan areas in Europe, Australia, Asia, and the United States [89] and aims to provide the possibility for most of the residents to fulfill their daily needs and activities within $15 \mathrm{~min}$ of walking or cycling.

Building on some European experiments, such as the Superilles in Barcelona and the Soft City in Copenhagen, the FMC identifies a comprehensive and interdisciplinary typology of a sustainable city based on proximity (a test was also done in Bogota). It is based on an urban planning process opposed to zoning-which separates residential areas from commercial, entertainment, and work areas-to build a polycentric city, with hybrid neighborhoods, where offices mix with houses, shops with schools, and health centers with museums. Bringing people closer to those places is intended to foster a better and more rapid understanding of citizens' problems, provide new answers to climate change issues, and stimulate neighborhood life and economic opportunities, even in marginal areas.

This paper aims to propose and test conditions for a modified and more granular CCCM indicator. Our unit of analysis is the city of Milano in its 88 neighborhoods. Over the years, the scholarly community and the municipality have underlined the relevance of CCIs in characterizing the city from a socioeconomic standpoint. Milano was found to specialize in the computer industry and advertising [70] as well as in content and information systems [90]. However, the statistical data used for these analyses (i.e., data related to economic activity provided by the Chamber of Commerce) made it necessary to focus on the provincial borders and not the city or the metropolitan city. Other studies with a more qualitative approach depicted Milan as a fashion city [91] focused on the cultural endowment [55] or measured the level of socio-material deprivation at a disaggregated level of the Milan province [92]. The preparatory work for applying to have the city be recognized as a UNESCO creative city of literature (2017) showed the methodological difficulties with demonstrating the importance of the publishing industry to the city's economy and vibrancy. More recent experiments in cultural mapping explored crowdsourced methodologies for data gathering at the neighborhood level on the city's cultural infrastructure [93].

The city of Milano has indicated its willingness to leverage citizens' participation and cultural presence to differentiate among Italian towns and to network with international peers (as with the World Culture Cities Forum). Starting from the Mayors' Agenda for a Green and Just Recovery-that specifically mentions the idea of the FMC as a framework of rebounding and reaffirming the commitment of cities to the Global Green New DealMilano has embraced this view with the 'COVID-19 Adaptation Strategy Milano 2020'.

It is interesting to note that culture is fully included among the essential proximity services in the founding program of Hidalgo's FMC and within Milan 2020. This common trait is consistent with the idea that in a knowledge-based city-highly immaterial, globalized, and interconnected-local elements are decisive [94] in determining residential and business location choices. The city manifests itself as a network of (more or less spontaneous) connections through which experiences characterized by a diverse environment are developed in a world where standardized and codified knowledge is easily accessible. This perspective relies on the networks generated by various local stakeholders as an engine for 
territorial development and embodies an idea of the city. Institutions are called upon to recognize and enhance existing connections rather than plan them from above. In this city vision, culture is a factor stimulating participation, which nurtures planning, a sense of belonging, and, thus, connections [95].

\section{Methodology}

We mapped the "presence of culture" at the neighborhood level to test the possibility of supporting policymakers' understanding of the potential relationship between cultural and creative dimensions and cities' sustainability [96] and actions toward cities' sustainability and equity $[72,97,98]$.

As Sacco and Vella [10] acknowledge: “ ... mapping does not only play a representational role in the cultural sphere, but also a definitional one: it is only through mapping that it becomes possible for experts, policymakers, and practitioners to develop a sound understanding of the spatial, functional, and organizational articulation of such activities, and to lay the premises for extrapolating future trends" (p. 1). For example, the ability of a city to include its residents and reduce inequalities (i.e., SDG 10) can be appreciated by knowing where cultural venues and facilities are physically located [98].

We created a geolocalized collection of information associated with cultural venues built through a stratification approach and increasingly precise granularity. The database (MapMI) collects over 13,000 records related to places that host or have temporarily or permanently hosted cultural and creative activities in the city of Milano since 2012 [93]. Each record contains core information, including name, address, borough, Nuclei di Identità Locale (NIL, i.e., neighborhood), main activity, institutional status, and main area of activity. Other relevant information is included, such as network memberships, activities offered, and participation in city events, together with closures and/or relocations. Finally, data collection was crowdsourced with the help of a cohort of students and independent organizations; researchers at the ASK Bocconi research center regularly checked for consistency and duplication. The data in the dataset were last updated in February 2020. The team is currently starting a revision of the effects of the pandemic on the presence of cultural venues and activities after the pandemic.

We then compared MapMI to the CCCM's composition. In a nutshell, CCCM is designed to help identify local strengths and opportunities and benchmark cities against similar urban centers using both quantitative and qualitative data. The quantitative information is captured in 29 indicators relevant to 9 dimensions reflecting 3 major facets of the cultural, social, and economic vitality of cities. These data are complemented by qualitative information including features ranging from the main cultural sites to the development of policy strategies and infrastructure (e.g., funds, tax incentives, creative incubators, and fab labs) that demonstrate a city's commitment to supporting culture and creativity (see for more details [56]). Figures 1-3 display the comparison between the properties of the indicators in the two datasets. Starting from the CCCM's properties, we matched the CCCM indicators (e.g., sights and landmarks) with the corresponding MapMI 'main activity' categories (e.g., churches, architectural buildings, parks, and public spaces). As the datasets' indicators did not always match, we identified the MapMI indicators that were closest to the CCCM ones or substituted them with more meaningful ones given the unit of analysis (NIL as opposed to city).

As to Figure 1, cultural venues and facilities and architectural buildings were underestimated, as the city is rich in private and public architectural landmarks of different styles.

Cultural participation was also measured differently from the CCCM by considering the presence of specific organizations targeting (voluntary) participation in diffused events in town.

The characterization of CCI within Figure 2 has used the following criteria. Cultural production groups companies and not-for-profit organizations involved in cultural production activities across different industries (i.e., audio-video, books, magazines, and newspapers). Commercial cultural venues include art galleries, bookstores (new and 
used books), and record stores. Creative economy groups professionals from the so-called creative industries. To highlight organizations that could be defined as creative (and not mere service providers), architects and photographers in the sample include only those participating in the "off" initiatives taking place during the Milano Design Week (as known as Fuorisalone). As it emerges from Figure 2, the shift in the focus based on the neighborhoods and on one city, together with the methodology followed to create the dataset call for a different characterization of the CCCM indicators, therefore a "greater distance" from it. At the same time, it makes possible to reach a high level of granularity in CCI definition and a more precise operationalization.

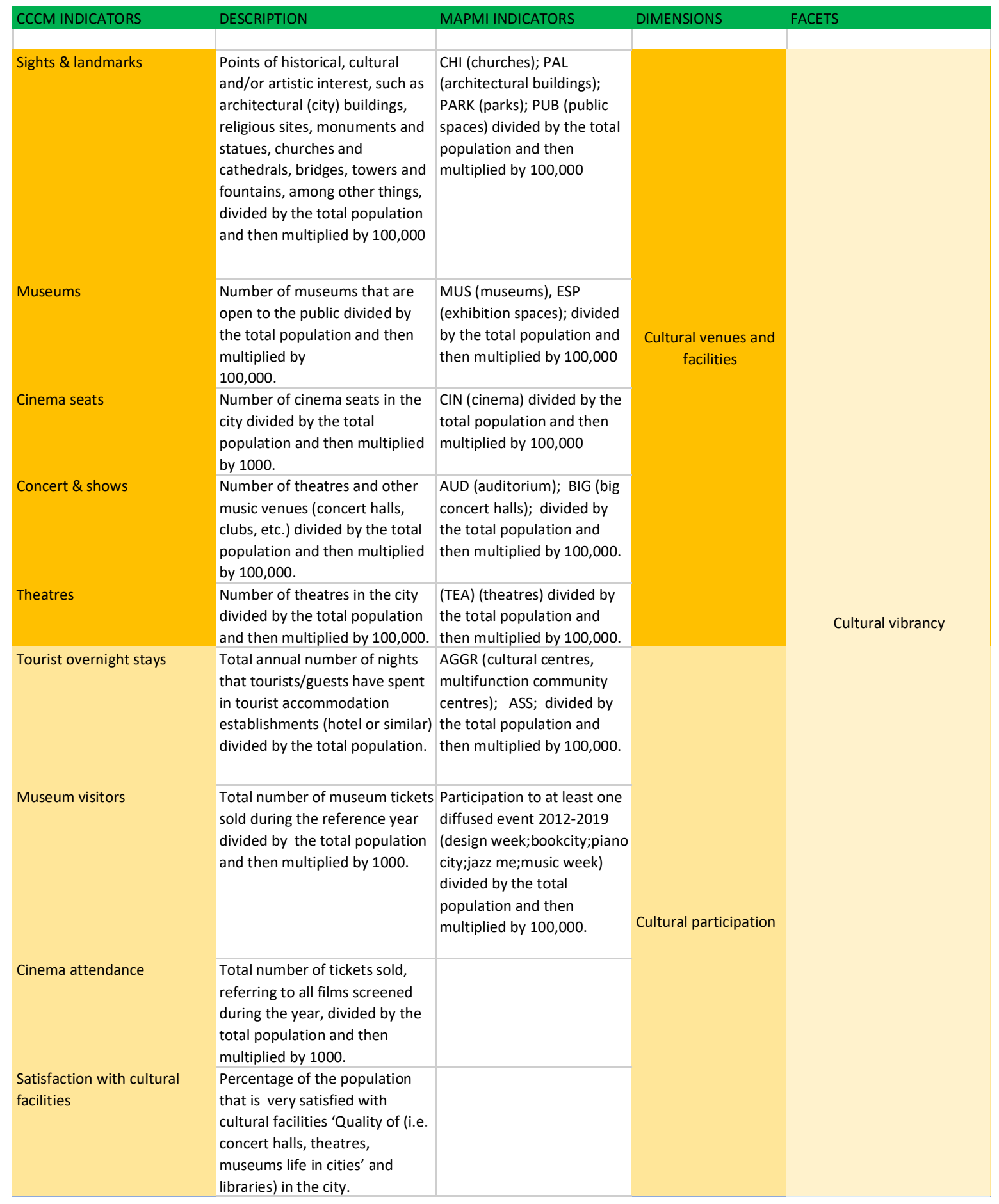

Figure 1. Variables selected for index creation: Cultural Vibrancy. 


\begin{tabular}{|c|c|c|c|c|}
\hline CCCM INDICATORS & DESCRIPTION & MAPMI INDICATORS & DIMENSIONS & FACETS \\
\hline $\begin{array}{l}\text { Jobs in arts, culture \& } \\
\text { entertainment }\end{array}$ & $\begin{array}{l}\text { Number of jobs in arts, culture- } \\
\text { and entertainment-related } \\
\text { activities such as performing } \\
\text { arts, museums and libraries, } \\
\text { divided by the total population } \\
\text { and then multiplied by } 1000 \\
\text { (NACE Rev. 2, R-U). }\end{array}$ & $\begin{array}{l}\text { Cultural production(AG } \\
\text { (literary agencies); EDI } \\
\text { (publishers); PROD } \\
\text { (production centers);TV } \\
\text {;RAD (radio) PER } \\
\text { (magazines) divided by the } \\
\text { total population and then } \\
\text { multiplied by } 100,000 .\end{array}$ & & \\
\hline $\begin{array}{l}\text { Jobs in media \& } \\
\text { communication }\end{array}$ & $\begin{array}{l}\text { Number of jobs in media and } \\
\text { communication-related } \\
\text { activities such as book and } \\
\text { music publishing, film } \\
\text { production and TV, divided by } \\
\text { the total population and then } \\
\text { multiplied by } 1000 \text { (NACE Rev. } \\
2, \mathrm{~J} \text { ). }\end{array}$ & $\begin{array}{l}\text { Commercial cultural venues } \\
\text { (GAL; (galleries); LIB } \\
\text { (bookstores) REC (record } \\
\text { stores); LIBUS (used books } \\
\text { stores) divided by the total } \\
\text { population and then } \\
\text { multiplied by } 100,000 \text {. }\end{array}$ & & \\
\hline Jobs in other creative sectors & $\begin{array}{l}\text { Number of jobs in professional, } \\
\text { scientific and technical, } \\
\text { administrative and support } \\
\text { service activities such as } \\
\text { architecture, advertising, } \\
\text { design, and photographic } \\
\text { activities, divided by the total } \\
\text { population and then multiplied } \\
\text { by } 1000 \text { (NACE Rev. 2, M-N). }\end{array}$ & $\begin{array}{l}\text { Creative economyARCH } \\
\text { (architectural firm); COW } \\
\text { (shared workspaces); FOTO } \\
\text { (photography); LEG } \\
\text { (bookbinding); PRJ (project } \\
\text { spaces); ART (artist studios) }\end{array}$ & & \\
\hline ICT patent applications & $\begin{array}{l}\text { Three-year average number of } \\
\text { ICT patent applications (e.g. } \\
\text { consumer electronics, } \\
\text { computers and } \\
\text { telecommunications) filed to } \\
\text { the European Patent Office by } \\
\text { priority year di- vided by the } \\
\text { total population and then } \\
\text { multiplied by } 1 \text { million. }\end{array}$ & $\begin{array}{l}\text { Knowledge economyRIC } \\
\text { (research centres); ARC } \\
\text { (archives) BIB (libraries) } \\
\text { divided by the total } \\
\text { population and then } \\
\text { multiplied by } 100,000 .\end{array}$ & $\begin{array}{l}\text { Intellectual property } \\
\text { \& innovation }\end{array}$ & Creative economy \\
\hline $\begin{array}{l}\text { Community design } \\
\text { applications }\end{array}$ & $\begin{array}{l}\text { Three-year average number of } \\
\text { Community Design applications } \\
\text { filed to the Office for } \\
\text { Harmonization in the Internal } \\
\text { Market (OHIM) divided by the } \\
\text { total population and then } \\
\text { multiplied by } 1 \text { million. }\end{array}$ & & & \\
\hline $\begin{array}{l}\text { Jobs in new arts, culture \& } \\
\text { entertainment enterprises }\end{array}$ & $\begin{array}{l}\text { Number of persons employed in } \\
\text { the enterprises established in } \\
\text { the reference year, divided by } \\
\text { the total population and then } \\
\text { multiplied by } 100,000 \text { (see } \\
\text { indicator } 10 \text { for NACE codes). }\end{array}$ & & \multirow{3}{*}{$\begin{array}{l}\text { New jobs in creative } \\
\text { sectors }\end{array}$} & \\
\hline $\begin{array}{l}\text { Jobs in new media \& } \\
\text { communication enterprises }\end{array}$ & $\begin{array}{l}\text { Number of persons employed in } \\
\text { the enterprises established in } \\
\text { the reference year, divided by } \\
\text { the total population and then } \\
\text { multiplied by } 100,000 \text { (see } \\
\text { indicator } 11 \text { for NACE codes). }\end{array}$ & & & \\
\hline $\begin{array}{l}\text { Jobs in new enterprises in } \\
\text { other creative sectors }\end{array}$ & $\begin{array}{l}\text { Number of persons employed in } \\
\text { the enterprises established in } \\
\text { the reference year, divided by } \\
\text { the total population and then } \\
\text { multiplied by } 100,000 \text { (see } \\
\text { indicator } 12 \text { for NACE codes). }\end{array}$ & & & \\
\hline
\end{tabular}

Figure 2. Variables selected for index creation: Cultural Vibrancy. 


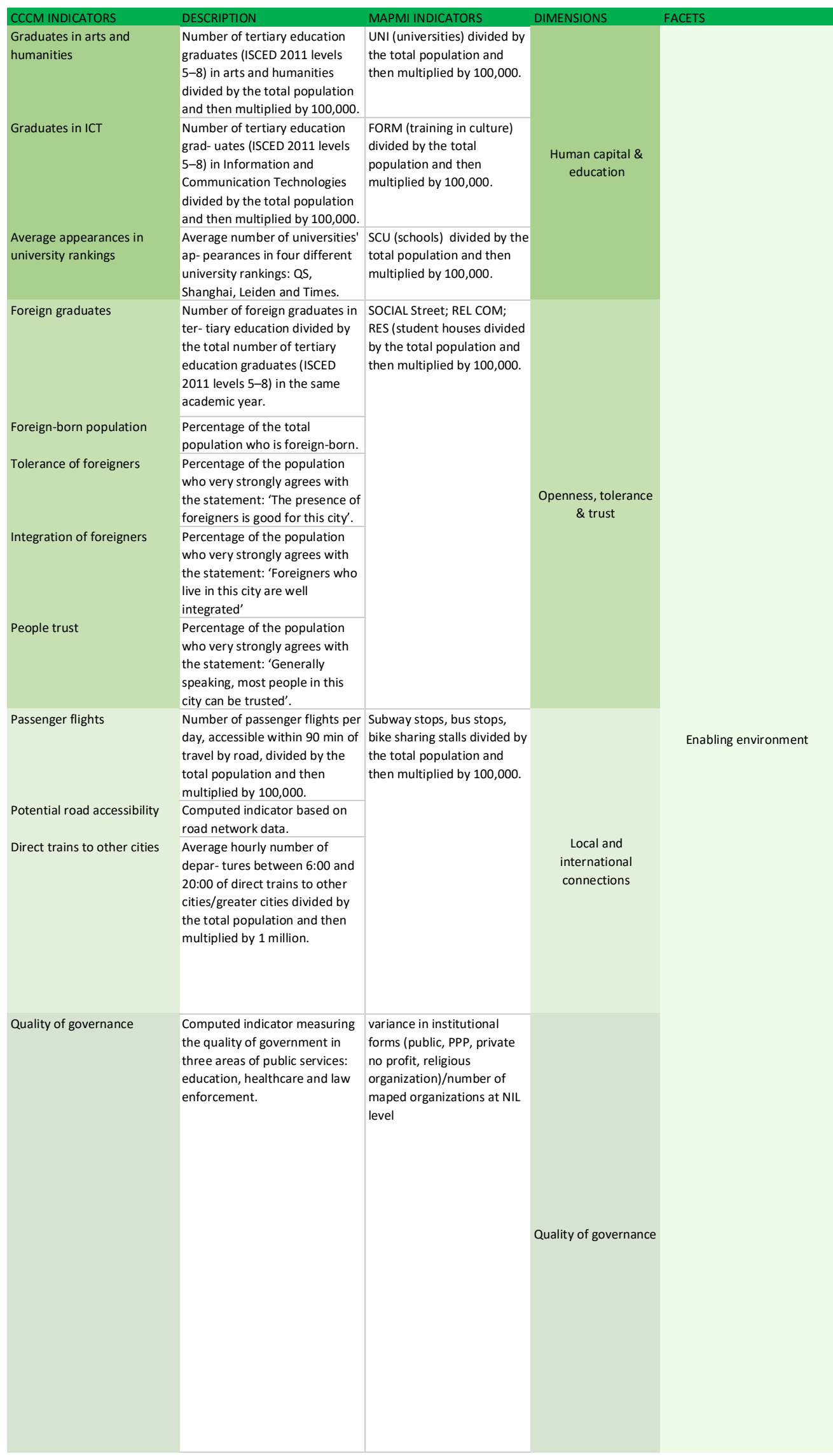

Figure 3. Variables selected for index creation: Enabling Environment. 
Knowledge economy, instead, groups organizations associated with research activities. We did not include data related to employment in these industries or the number of patents, as it did not seem appropriate at the neighborhood level.

The Human Capital and Education dimension included within Figure 3 was defined considering three types of educational organizations: schools, universities, and academia. These are organizations involved in training individuals for the arts and cultural sectors, even amateurs, notwithstanding the ambiguous differentiation between production, participation, and practice in the arts. We felt that number of graduates from specific universities was not the best proxy to define the presence of human capital at the neighborhood level.

Still looking at Figure 3, the Openness and Tolerance dimension was built considering three categories of organizations: social streets, religious communities, and university residences. Social streets consist of groups of residents willing to strengthen social ties and inclusion at the street level. It is a typified type of bottom-up initiative that started in Bologna in 2013 and progressively extended into other Italian cities. Religious communities other than Roman Catholic, Protestant, and Jewish communities do not have churches that may be considered cultural landmarks in Milano. Therefore, they were mapped and believed in their social meaning. Finally, university residences are inhabited by students not residing in Milano and who often come from abroad. They typically spend from one to five years living in the same neighborhood while attending their program.

Finally, Figure 3 includes the indicators for local and international connections created by counting subway stops, train stations, circle-line stops, and bike-sharing stations per NIL and summing them up. Unlike CCCM, the mobility indicator measures mobility opportunity within the city, as opposed to accessibility to the city. Lastly, the governance index at the neighborhood level was constructed in two steps. First, we classified all organizations considered in the analysis per their juridical form (e.g., public, private, public-private partnership, no profit, and religious organization); second, we calculated the variance in juridical forms on the total number of organizations per NIL in the database.

All other indicators were divided by the NIL's population and then multiplied by 100,000 as per the CCCM.

Figure 4 identifies the presence in the city of the variables considered and the average presence per NIL.

Figure 4 applies the indicators provided in Figure 3 on the city as a whole. For each variable considered, the figure lists the total number of venues at city level, and the average number per NIL. For each category, a synthetic index is created by calculating the total number of venues per 100,000 residents. The results show how the city is rich in cultural venues and facilities, with architectural landmarks being significantly under-represented. Events and initiatives targeting cultural participation are numerous and significant in size. More specifically, some diffused events in the town (e.g., Piano City and Bookcity) have been designed to be spread throughout the city. In contrast, Fuorisalone-the city initiative associated with Design Week-has traditionally been concentrated in a few neighborhoods and has spread out in recent years.

Cultural and creative industries are heavily represented in the town. However, the creative sector is significantly under-represented if we specifically consider architects, designers, photographers, and web agencies. They are included in the sample to the extent they have taken part in at least one edition of Fuorisalone between 2012 and 2019. The relevance of the human capital factor clearly shows the attractiveness of the city of Milano as a place to study, given the variety and quality of its educational infrastructure. 


\begin{tabular}{|c|c|c|c|}
\hline Variable & Total number & Average per NIL & \multirow{16}{*}{ 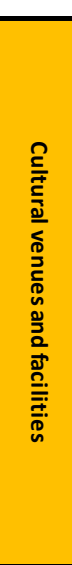 } \\
\hline \multicolumn{3}{|l|}{ SIGHTS AND LANDMARKS } & \\
\hline Churches & 382 & 4 & \\
\hline Parks & 66 & 1 & \\
\hline Landmarks & 359 & 4 & \\
\hline \multicolumn{3}{|l|}{ MUSEUMS } & \\
\hline Museums & 86 & 1 & \\
\hline Exhibition spaces & 55 & 1 & \\
\hline \multicolumn{3}{|l|}{ CINEMAS } & \\
\hline Cinemas & 33 & 0 & \\
\hline \multicolumn{3}{|l|}{ CONCERT HALLS } & \\
\hline Auditorium big venues & 22 & 0 & \\
\hline \multicolumn{3}{|l|}{ THEATRES } & \\
\hline Theatres & 79 & & \\
\hline TOTAL & 1082 & 12 & \\
\hline Cultural venues per 100,000 inhabitants & & 78 & \\
\hline \multicolumn{3}{|l|}{ ONGOING INITIATIVES } & \multirow{12}{*}{ 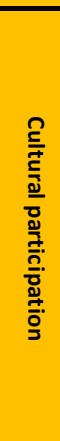 } \\
\hline \multirow{2}{*}{\multicolumn{3}{|c|}{$\begin{array}{l}\text { Aggregation centres/cultural associations } \\
\text { EVENTS }\end{array}$}} & \\
\hline & & & \\
\hline Fuorisalone & 3833 & 44 & \\
\hline Bookcity & 1892 & 22 & \\
\hline Jazzmi & 227 & 3 & \\
\hline Music Week & 200 & 2 & \\
\hline Piano city & 738 & 8 & \\
\hline Photo Week & 376 & 4 & \\
\hline Art Week & 128 & 1 & \\
\hline TOTAL & 7945 & 90 & \\
\hline Cultural venues per 100,000 inhabitants & & 571 & \\
\hline \multicolumn{3}{|l|}{ CULTURAL INDUSTRIES } & \multirow{8}{*}{ 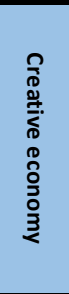 } \\
\hline Cultural production & 770 & 9 & \\
\hline Commercial cultural venues & 627 & 7 & \\
\hline \multicolumn{3}{|l|}{ CREATIVE INDUSTRIES } & \\
\hline Creative economy & 459 & 5 & \\
\hline Clubs & 80 & 1 & \\
\hline TOTAL & 1936 & 22 & \\
\hline CCI per 100,000 inhabitants & & 139 & \\
\hline \multicolumn{3}{|l|}{ RESEARCH } & \multirow{4}{*}{ 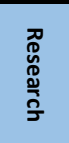 } \\
\hline Knowledge economy & 495 & 6 & \\
\hline TOTAL & 1936 & 22 & \\
\hline Research per 100,000 inhabitants & & 36 & \\
\hline \multicolumn{3}{|l|}{ HUMAN CAPITAL AND EDUCATION } & \multirow{6}{*}{ 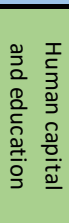 } \\
\hline Universities/Academia & 108 & 1 & \\
\hline Training in the arts & 217 & 2 & \\
\hline Schools & 655 & 7 & \\
\hline TOTAL & 980 & 11 & \\
\hline Human Capital \& Education per 100,000 inhabitants & & 70 & \\
\hline OPENNESS AND TOLERANCE & & & \\
\hline Social streets & 77 & 1 & \\
\hline Religious communities & 49 & 1 & 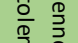 \\
\hline Student houses & 115 & 1 & ฏ \\
\hline TOTAL & 241 & 3 & \\
\hline Openness \& Tolerance per 100,000 inhabitants & & 17 & \\
\hline MOBILITY & & & \\
\hline Mobility connections & 373 & 4 & $\frac{3}{0}$ \\
\hline TOTAL & 373 & 4 & 严 \\
\hline Mobility per 100,000 inhabitants & & 27 & \\
\hline Variance in the institutional mix & & $24 \%$ & 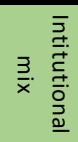 \\
\hline Population & $1,392,502$ & 15.824 & \\
\hline
\end{tabular}

Figure 4. Cultural venues and activities. 
The Enabling Environment has become progressively more international in the mix of geographic provenances of talents and residents and shows a growing interest in multicultural and intercultural projects. Another area of recent local investment is increased mobility and the intermodality of local transportation. Finally, we characterized the organizations involved in creative and cultural activities based on their legal form. The idea is to evaluate the composition and diversity at the city and neighborhoods level. Even though the aim is descriptive, the assumption is that a mix of institutional forms can adequately sustain the interplay between economics and not economic instances and, therefore, a balance between conservation and innovations in the field. We counted the number of public, private, public-private, nonprofit, religious, and universities in the city and within each NIL. Then we calculated the standard deviation for each type of organization and divided it by the number of organizations present in each NIL and the overall city. The higher the final score, expressed as a percentage, the skewed towards a particular institutional form is the presence of the organizations in each NIL and the city, potentially showing the vocation of the area. At the city level, the mix of institutional forms in the sectors considered shows the dominance of private companies, with public and no-profit organizations well represented. Religious organizations are less present with a focus on specific industries and activities.

\section{Analysis of Data}

Data provided in Figure 4 consider the city as a homogeneous whole, and de facto provides a modified version of CCCM. In practice, though, we are well aware that significant differences occur within the city in terms of cultural offer and demand, infrastructures, and sociodemographic and economic texture. To better appreciate the specificity of individual NILS in their cultural characterization, we decided to calculate the indicators described in Figures 3 and 4 by NIL. We decided to run a specific analysis by grouping Nils per total population. As it can be seen from the following figures, NILS differ significantly by size and by population. Moreover, indicators of cultural offer and participation per 100,000 residents at the NIL level offer a more precise characterization of the city's cultural and creative texture. However, this indicator is sensitive to the size of the resident population and less informative in the case of very low numbers. We, therefore, first clustered the NILs into four groups by the number of residents and then started analyzing the composition of each cluster based on the NILs' characteristics.

As shown in Figure 5, twenty-three neighborhoods have less than 4200 inhabitants each. They include areas occupied by a green area or a large organization (a hospital, a general market, or an industrial building). Two of them are the central parks in town and scored highly and are attractive in all the dimensions considered. Their common characteristic is a very low population density. Therefore, their attractiveness from a cultural point of view is only determined by their position in city geography. Consequently, it is not surprising that the two central parks (Sempione and Giardini) are exceptionally rich in cultural and creative presence, particularly events. Generally speaking, and not surprisingly given the incidence of green areas, they are characterized by a level of temporary activities above the city average.

The remaining 65 neighborhoods are significantly different in size, ranging from 4700 to over 62,000 residents. The average size is 16,000 inhabitants, and the median value is 15,000 inhabitants.

The second least populated group of neighborhoods includes 21 NILs, which are relatively less affluent in cultural landmarks and participation in cultural events than other areas.

Neighborhoods appearing in Figure 6 used to be either peripheral or industrial/infrastructure areas but have enjoyed in many cases specific regeneration projects (such as the relocation of a university to a vast post-industrial setting, as in the case of Bicocca, or a real-estate-driven requalification, as in the case of Porta Garibaldi) via a series of private-public partnerships. In many instances (Porta Garibaldi, Lambrate, Porta Vigentina, and Moncucco), the creative 
economy mingles with traditional cultural industries to qualify those areas that are nonetheless facing gentrification issues. Education (mainly tertiary education) does play a significant role in these areas, as campus expansion has shifted the composition of residents and daily visitors.

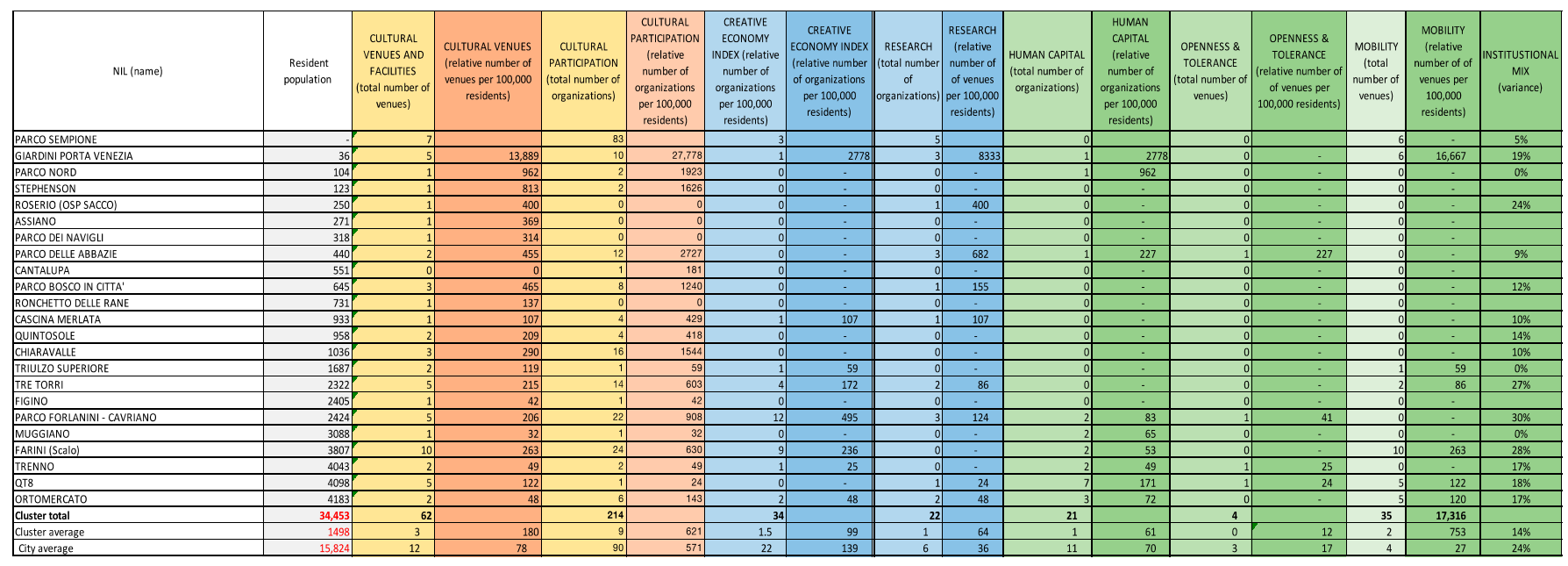

Figure 5. Size matters: The less-populated neighborhoods.

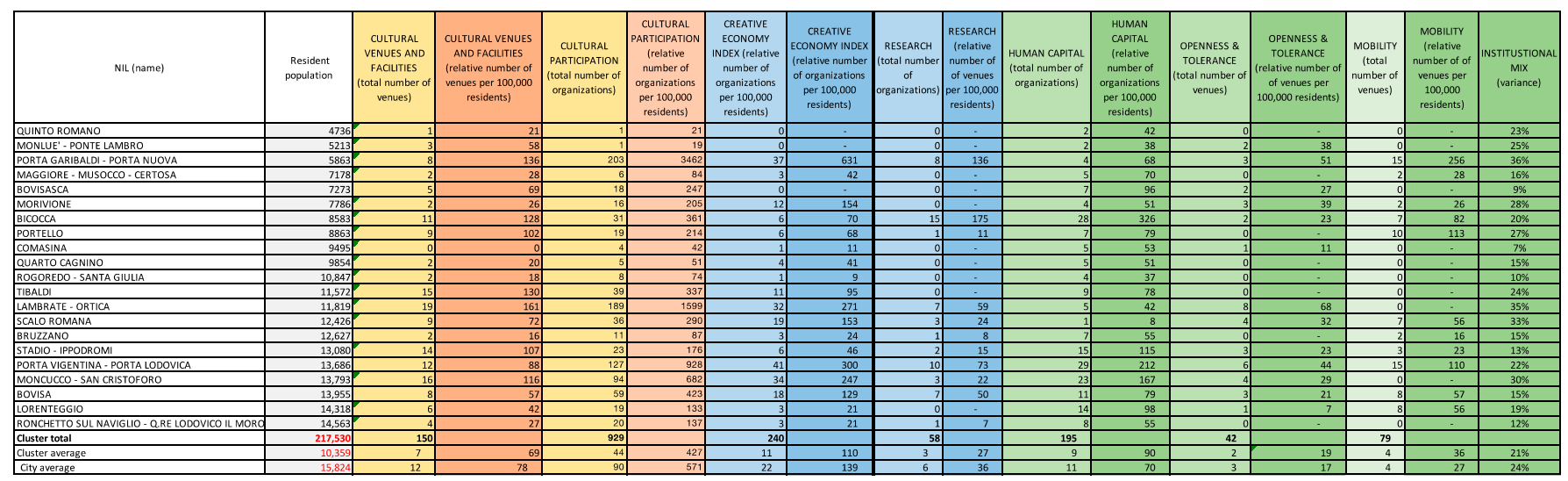

Figure 6. Size matters: The relatively small neighborhoods.

The third group of neighborhoods in Figure 7 includes a very diverse mix of 24 NILs with a high degree of variance in their cultural identity. Some traditional high- and middleclass residential neighborhoods (Pagano, Magenta, Porta Genova, and De Angelis) mix with more popular areas (Barona, Adriano, and Ghisolfa), places undergoing transformation and gentrification (Isola), and areas characterized by high flows of people due to the presence of universities, hospitals, and tourists (Duomo), the tribunal (Guastalla), commercial activities (Duomo, Porta Romana, Magenta, and Porta Genova), or transportation hubs (Centrale). Not surprisingly, this heterogeneous group of NILs scores systematically higher than the other clusters in all cultural vitality indicators.

The last group of NILs appearing in Figure 8 gathers the most densely populated areas in town. In many instances, they are characterized by various ethnicities, and often residents are relatively young. Four of them (Villapizzone, Bande Nere, Loreto, and Buenos Aires) could be compared to a mid-sized Italian city (as a reference, 100 cities in Italy have more than 60,000 inhabitants). Access to transportation and mobility affect the neighborhood's dynamism and cultural attractiveness. 


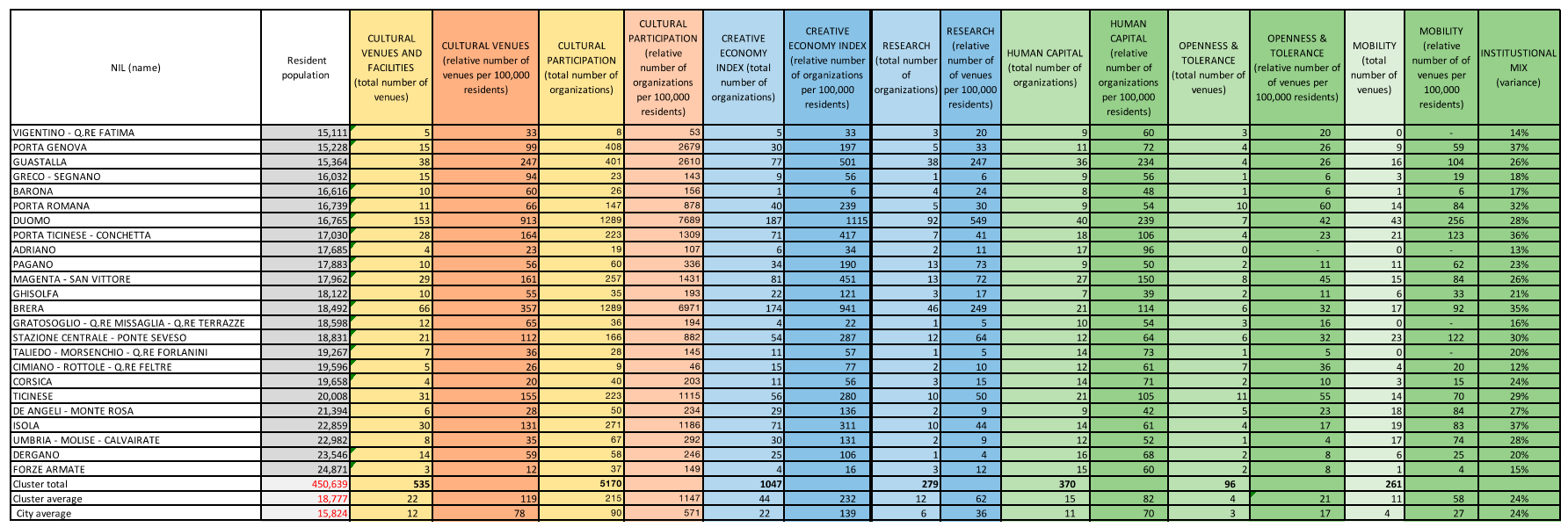

Figure 7. Size matters: A more diversified territory.

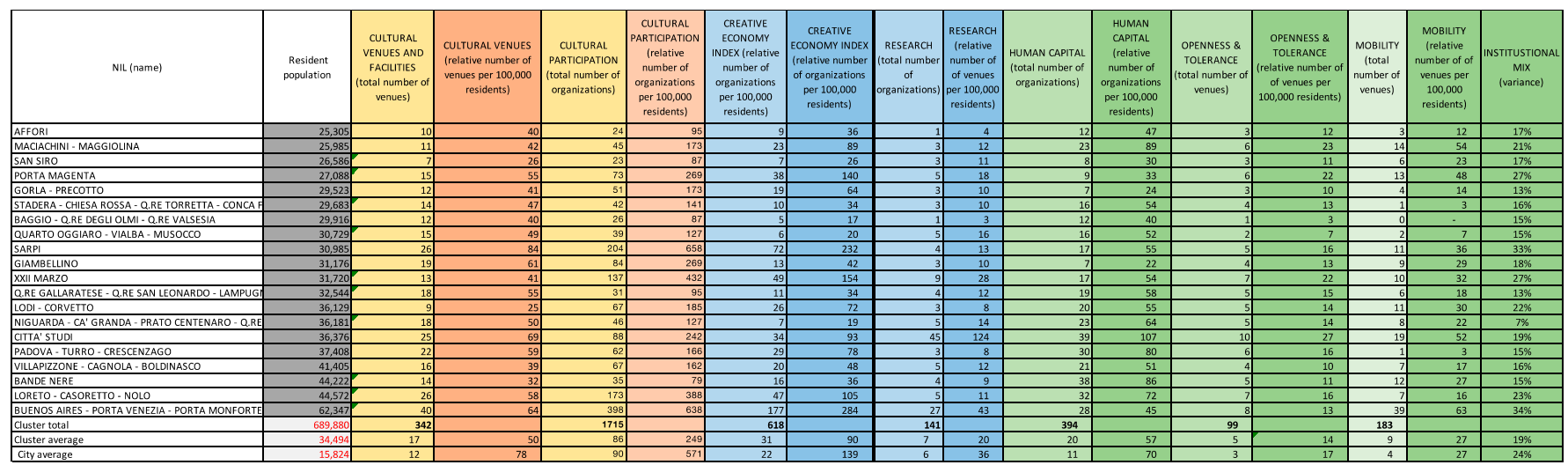

Figure 8. Size matters: The biggies.

\section{Cultural Vocation}

The 15-minute city posits the need to offer all kinds of services within walking distance. To check for the ability of different NILs to offer enough cultural variety and depth, we selected the top ten NILs for each dimension considered in the index and then looked at the cultural variety within each dimension.

Figure 9 shows the top ten neighborhoods according to each dimension used to build the global indicator of cultural vitality shown in Figure 1, independently of the number of residents.

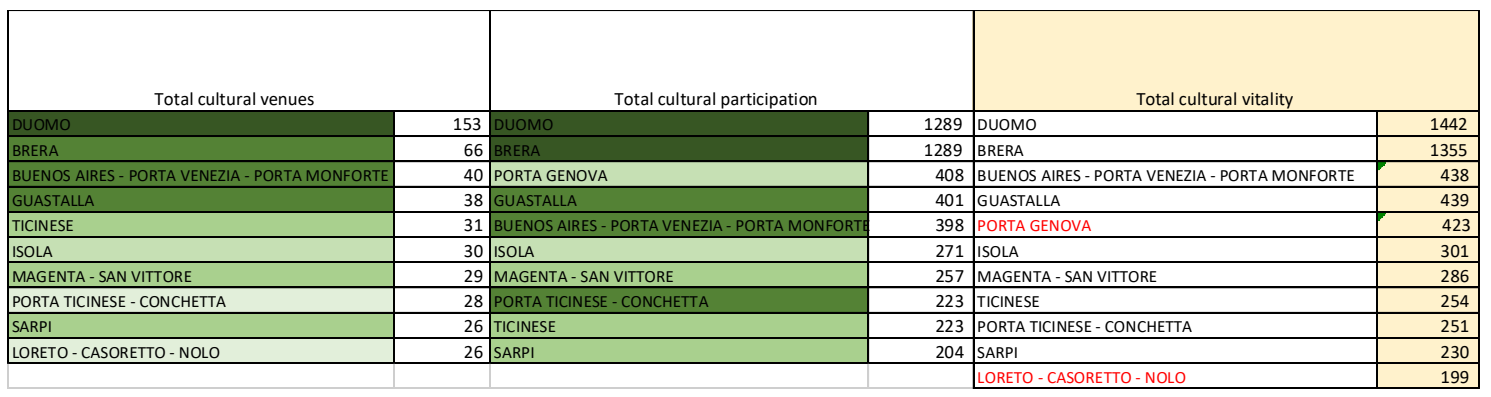

Figure 9. The top ten NILs in the Cultural Vitality indicator.

The last column of Figure 9 shows the ranking for the overall dimension of cultural vitality, which is the sum of the scores for the items composing each subdimension. In the first two columns, the different shades of color reflect the scores of the other neighborhoods for each sub-indicator in the total cultural venues and total cultural participation indicators. 
The darker the color, the more the NIL is in the top ten for each indicator composing the subdimensions.

In the case of cultural participation, it is interesting to note the NILs in the top ten list for specific diffused events, but not in the overall top ten list for cultural participation: Porta Garibaldi, Porta Vigentina, and Lambrate are heavily characterized by their involvement in more than one diffused event; Moncucco and Gratosoglio are particularly active due to the presence of cultural associations and aggregation centers; and Loreto, Dergano, and Lodi leverage both events and associations in order to mobilize local communities and activate cultural participation. Given the high level of participation in diffused cultural events, Porta Genova is in the top ten list for total cultural vitality, even though it is not in the top ten list for cultural venues. Generally speaking, though, the neighborhoods rich in landmarks are also attractive in terms of temporary events.

Figure 10 explores the concentration of creative economy indicators. As highlighted above, the different shades of color reflect the presence of sub-indicators for each component in the top ten NILs. In the total creative economy indicator, NILs in red are those absent in both sub-indicators. As far as the distribution of cultural production organizations is concerned, Pagano and Porta Vigentina show clusters of organizations. Outside of the top ten NILs, commercial and cultural venues are concentrated in two lively neighborhoods such as Garibaldi and XXII Marzo. Loreto, Porta Romana, and Porta Genova are strong in creative organizations. It is interesting to note that some areas (Loreto, Lodi, XXII Marzo, Garibaldi, and Forlanini) are hubs of nightlife and clubbing.

\begin{tabular}{|c|c|c|c|c|c|}
\hline \multicolumn{2}{|l|}{ Cultural and creative economy } & \multicolumn{2}{|l|}{ Knowledge economy } & \multicolumn{2}{|l|}{ Total creative economy } \\
\hline DUOMO & 187 & DUOMO & 92 & DUOMO & 279 \\
\hline BUENOS AIRES - PORTA VENEZIA - PORTA MONFORTE & 177 & BRERA & 46 & BUENOS AIRES - PORTA VENEZIA - PORTA MONFORTE & 204 \\
\hline BRERA & 174 & CITTA' STUDI & 45 & BRERA & 220 \\
\hline ISOLA & 81 & GUASTALLA & 38 & GUASTALLA & 110 \\
\hline MAGENTA - SAN VITTORE & 77 & BUENOS AIRES - PORTA VENEZIA - PORTA MONFORTE & 27 & ISOLA & 91 \\
\hline GUASTALLA & 72 & BICOCCA & 15 & MAGENTA - SAN VITTORE & 90 \\
\hline SARPI & 71 & MAGENTA - SAN VITTORE & 13 & STAZIONE CENTRALE - PONTE SEVESO & 83 \\
\hline STAZIONE CENTRALE - PONTE SEVESO & 71 & PAGANO & 13 & CITTA' STUDI & 79 \\
\hline PORTA TICINESE - CONCHETTA & 56 & STAZIONE CENTRALE - PONTE SEVESO & 12 & SARPI & 75 \\
\hline TICINESE & 54 & ISOLA & 10 & TICINESE & 64 \\
\hline
\end{tabular}

Figure 10. The top ten NILs in the Creative Economy indicator.

Figure 11 explores the concentration of Enabling Environment indicators. As happened for the dispersion of individual components of the cultural and creative economy, some NILs that are not in the top ten list for the global indicator are still part of the top ten indicators of the subdimensions. Therefore, it is interesting to note the relevance of two large neighborhoods-Moncucco and Niguarda-due to the concentration of schools/training centers in the arts and creative industries. Moncucco also hosts university residences, while Villapizzone is rich in schools and religious communities, highlighting the social diversity.

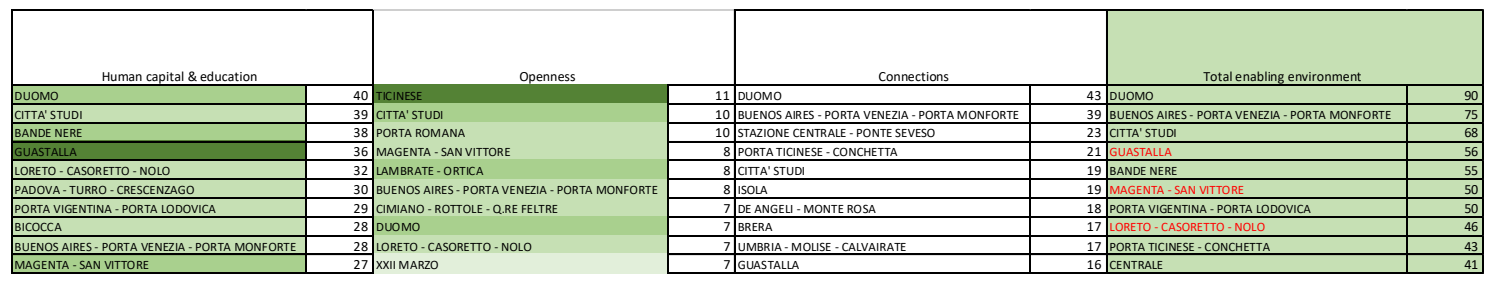

Figure 11. The top ten NILS in the Enabling Environment indicator.

If we compare the "top ten" in the three different categories, we can identify two major clusters: 
Neighborhoods are characterized by many creative, educational, and social initiatives and are very strong in terms of cultural institutions. Not surprisingly, these are the central neighborhoods of Duomo, Buenos Aires, Guastalla, and Magenta.

Neighborhoods leveraging cultural participation, social inclusion, and a dense presence of creative industries to create a nurturing and attractive environment from a cultural point of view include Brera, Isola, Ticinese, Sarpi, Città Studi, and Loreto. While they have become progressively more attractive for commercial and tourist activities (as in Brera, Isola, and Sarpi), they also are fields of debate and reflection on the potential negative impact of gentrification, particularly as far as the cost of real estate is concerned.

As expected, these same neighborhoods are well connected to the rest of the city, allowing for good mobility.

\section{Discussions and Conclusions}

In this paper, we adapted and applied the CCCM framework to the individual neighborhoods of Milano to explore the potential of the model at a more granular unit of analysis. Through the mapping of a wide variety of cultural and social organizations, we made visible the presence of neighborhoods rich in nightlife, creativity, and cultural participation in addition to the traditionally culturally dense areas of the city center. Our effort contributes to the ongoing debate on CCIs and their role in local development in three directions.

First, the paper makes a methodological contribution by translating, adapting, and supplementing the CCCM index and its subdimensions to spatially discriminate at a more granular level the cultural and creative vitality within the city. Our operationalization of culture expands the nomological set of indicators usually proposed in previous research by including any organization active in temporary events. We believe this is an essential element to be introduced in the debate on culture at the city level, particularly considering the penetration and diffusion of Agenda 2030. Cultural vitality is not only represented by the activity of ongoing organizations-usually including existing public, private, and nonprofit organizations-but in their ability to develop temporary and long-term partnerships with different stakeholders. Lastly, it explores crowdsourcing as a research method in the social sciences.

Second, from a policymaking point of view, this work offers a tool to support the growing debate on the 15-minute city by exploring the diverse presence of cultural and creative activities within the municipality and their location. Urban areas are not homogeneous, and neighborhoods can be considered to be spatially identified geographic areas within larger cities expressing different historical traces, local identities, and human networks. Exploring diversity through this lens is even more critical if we consider that transformations in land cost, social mix, economic activity, and culture occur to a different extent and at different times at the scale of city neighborhoods.

As a city can be seen as a unique integration of distinctive and dynamic neighborhoods, the paper enriches our understanding of heterogeneity in creative cities. Proximity represents a new guiding principle for city policymaking; as such, it constitutes an antithesis to previous orientations towards urban design, in which single-use districts and long-distance commuting were the rules. However, the development of proximity-driven local policies calls for a non-stereotypical understanding of each individual neighborhood's character, not limited to a basic site description (i.e., the cultural infrastructure) but involving what occurs within those venues (i.e., the cultural initiatives) and the interplay of formal and informal organizations engaged in such initiatives (i.e., cultural governance). This approach offers a more diverse (and hopefully more inclusive) view of the role of cultural organizations other than cultural institutions at the neighborhood level. This is particularly relevant in more recently established and peripheral areas that might be culturally vibrant and support diverse cultural expressions, even though they lack established institutions (such as museums).

Third, from a theoretical perspective, we have contributed to the reflection on cultural vitality by looking at the core activities of specific organizations involved in different edu- 
cational, cultural, and social projects. We, therefore, moved from looking at participation only in terms of audiences to analyzing the type of involvement these organizations have as their core activities (e.g., associations, cultural hubs, and so on) concerning the city.

There are several limitations to this study. The indicators provided are still quite rough, without any thought given to their relative importance depending on the socioeconomic priorities at the city level. Additionally, while the extreme granularity of the data represents one of the strengths of this work, it makes it difficult to compare our results to those of different cities. However, the approach used to adapt the CCCM index and the proposed measures can also be applied in other cities, increasing the comparability. Notwithstanding the granularity of the data, including explicitly in the analysis the geography of the neighborhoods (e.g., the presence of hills, rivers, parks, etc.) could undoubtedly enrich our understanding of their diversity and functional uniqueness. Additionally, the presence of private and not-for-profit organizations, which are much more volatile than public ones, requires significant data-checking and maintenance efforts. Future research can start to address some of these limitations. Finally, regarding proximity-driven cultural policies, it is worth emphasizing that a neighborhood's composition (e.g., local population, commuters, and tourists) and the residential composition (e.g., ethnicity and age) shape the neighborhood's structure and needs. While these elements are beyond the scope of this paper, they affect the quality of the neighborhood as an enabling environment for culture and, more generally, should be considered in the decision-making process related to cultural policies. Along this line, further research is needed to explore theoretically and empirically how the interplay between different stakeholders and their demands can be managed effectively and their impact on the evolution of and strategy related to cultural policies.

Author Contributions: Conceptualization, P.D. and A.M.; Data curation, A.B.; Formal analysis, P.D. and A.B.; Methodology, A.B.; Resources, A.B.; Supervision, P.D.; Validation, A.M.; Writing-original draft, P.D. and A.M.; Writing-review \& editing, A.B. All authors have read and agreed to the published version of the manuscript.

Funding: This research received no external funding.

Conflicts of Interest: The authors declare no conflict of interest.

\section{References}

1. DCMS (Department for Culture, Media and Sport). Creative Industries Mapping Document 2001; DCMS: London, UK, 2001.

2. DCMS (Department for Culture, Media and Sport). Creative Industries Economic EstimatesTechnical Note-February 2010; DCMS: London, UK, 2010. Available online: https://www.gov.uk/government/uploads/system/uploads/attachment_data/file/7841 8/Creative_Industries_Economic_Estimates_2010_technica_note.pdf (accessed on 20 September 2021).

3. UNESCO. Universal Declaration on Cultural Diversity; UNESCO: Paris, France, 2001. Available online: http://unesdoc.UNESCO. org/images/0012/001271/127160m.pdf (accessed on 20 September 2021).

4. UNESCO. Convention for the Safeguarding of the Intangible Cultural Heritage; UNESCO: Paris, France, 2003.

5. UNESCO. UNESCO Framework for Cultural Statistics; UNESCO: Paris, France, 2009.

6. Caves, R.E. Creative Industries: Contracts between Art and Commerce (No. 20); Harvard University Press: Cambridge, CA, USA, 2000.

7. Jones, P.; Comfort, D.; Eastwood, I.; Hillier, D. Creative Industries: Economic Contributions, Management Challenges and Support Initiatives. Manag. Res. News 2004, 27, 134141. [CrossRef]

8. Scott, A.J. Creative cities: Conceptual issues and policy questions. J. Urban Aff. 2006, 28, 1-17. [CrossRef]

9. Sacco, P.L.; Ferilli, G.; Blessi, G.T.; Nuccio, M. Culture as an engine of local development processes: System-wide cultural districts I: Theory. Growth Chang. 2013, 44, 555-570. [CrossRef]

10. Sacco, P.L.; Vella, G. Introduction to Valletta 2018 cultural mapping: Debating space and place. City Cult. Soc. 2017, 11, 1-3. [CrossRef]

11. Santagata, W. Cultural districts and their role in economic development. In Handbook of the Economics of Art and Culture; Ginsburgh, V., Throsby, D., Eds.; Elsevier: Amsterdam, The Netherlands, 2006; pp. 1100-1119.

12. Throsby, D. Economics and Culture; Cambridge University Press: New York, NY, USA, 2001.

13. Towse, R. A Handbook of Cultural Economics; Edward Elgar Publishing: Cheltenham, UK, 2003. [CrossRef]

14. Bertacchini, E.; Borrione, P. The geography of the Italian creative economy: The special role of the design and craft-based industries. Reg. Stud. 2013, 47, 135-147. [CrossRef]

15. Boix, R.; Capone, F.; De Propris, L.; Lazzeretti, L.; Sanchez, D. Comparing creative industries in Europe. Eur. Urban Reg. Stud. 2014, 23, 935-940. [CrossRef] 
16. Cooke, P.; Lazzeretti, L. (Eds.) Creative Cities, Cultural Clusters and Local Development; Edward Elgar: Cheltenham, UK, 2008. [CrossRef]

17. Mommaas, H. Cultural clusters and the post-industrial city: Towards the remapping of urban cultural policy. Urban Stud. 2004, 41,507-532. [CrossRef]

18. Cruz, S.; Teixeira, A.A. Assessing the magnitude of creative employment: A comprehensive mapping and estimation of existing methodologies. Eur. Plan. Stud. 2014, 22, 2172-2209. [CrossRef]

19. Cruz, S.S.; Teixeira, A.A. The magnitude of creative industries in Portugal: What do the distinct industry-based approaches tell us? Creat. Ind. J. 2015, 8, 85-102. [CrossRef]

20. Markusen, A.; Nicodemus, A.G.; Giarratani, F.; Hewings, G.; McCann, P. Spatial divisions of labor: How key worker profiles vary for the same industry in different regions. In Handbook of Industry Studies and Economic Geography; Edward Elgar Publishing: Cheltenham, UK, 2013.

21. Markusen, A.; Wassall, G.H.; DeNatale, D.; Cohen, R. Defining the creative economy: Industry and occupational approaches. Econ. Dev. Q. 2008, 22, 24-45. [CrossRef]

22. Higgs, P.; Cunningham, S.; Bakhshi, H. Beyond the Creative Industries: Mapping the Creative Economy in the United Kingdom; Nesta: London, UK, 2008.

23. UNCTAD (United Nations Conference on Trade and Development). Creative Economy Report 2008: The Challenge of Assessing the Creative Economy Towards Informed Policy-making; United Nations: Geneva, Switzerland, 2008. Available online: http://unctad.org/fr/ Docs/ditc20082cer_en.pdf (accessed on 20 September 2021).

24. Thorsby, D. The Economics of Cultural Policy; Cambridge University Press: Cambridge, UK, 2010.

25. KEA. The Economy of Culture in Europe; European Commission: Brussels, Belgium, 2006.

26. KEA. Measuring Economic Impact of CCIs Policies: How to Justify Investment in Cultural and Creative Assets; European Commission, Directorate-General for Education and Culture: Brussels, Belgium, 2012.

27. Santagata, W. Libro Bianco Sulla Creativita': Per un Modello Italiano di Sviluppo; Universita Bocconi: Milano, Italy, 2009.

28. DCMS (Department for Culture, Media and Sport). Creative Industries Economic Estimates Full Statistical Release 8 December 2011; DCMS: London, UK, 2011.

29. UNESCO. UNESCO Framework for Cultural Statistics-Handbook No. 1 Measuring the Economic Contribution of Cultural Industries. 2012. Available online: http:/ / uis.unesco.org/sites/default/files/documents/measuring-the-economic-contribution-ofcultural-industries-a-review-and-assessment-of-current-methodological-approaches-en_1.pdf (accessed on 20 September 2021).

30. OECD. Culture and Local Development; OECD Publications: Paris, France, 2005.

31. Florida, R. The Rise of the Creative Class: And How It's Transforming Work, Leisure, Community, and Everyday Life; Basic Books: London, UK, 2002.

32. Bakhshi, H.; MacVittie, E.; Simmie, J. Creating innovation. Do the creative industries support innovation in the wider economy? NESTA 2008. [CrossRef]

33. Innocenti, N.; Lazzeretti, L. Do the creative industries support growth and innovation in the wider economy? Industry relatedness and employment growth in Italy. Ind. Innov. 2019, 26, 1152-1173. [CrossRef]

34. Müller, K.; Rammer, C.; Trüby, J. The role of creative industries in industrial innovation. Innovation 2009, 11, 148-168. [CrossRef]

35. Pratt, A.C.; Jeffcutt, P. Creativity, innovation and the cultural economy. In Snake Oil for the Twenty-First Century? Creativity, Innovation and the Cultural Economy; Routledge: London, UK, 2009; pp. 1-20. [CrossRef]

36. Grossi, E.; Blessi, G.T.; Sacco, P.L. Magic moments: Determinants of stress relief and subjective wellbeing from visiting a cultural heritage site. Cult. Med. Psychiatry 2019, 43, 4-24. [CrossRef] [PubMed]

37. Reyes-Martínez, J.; Takeuchi, D.; Martínez-Martínez, O.A.; Lombe, M. The role of cultural participation on subjective well-being in Mexico. Appl. Res. Qual. Life 2021, 16, 1321-1341. [CrossRef]

38. Helliwell, J.F.; Layard, R.; Sachs, J.; De Neve, J.E. World Happiness Report. 2020. Available online: https://happiness-report.s3 .amazonaws.com/2020/WHR20.pdf (accessed on 20 September 2021).

39. Sasaki, M. Urban regeneration through cultural creativity and social inclusion: Rethinking creative city theory through a Japanese case study. Cities 2010, 27, S3-S9. [CrossRef]

40. Moulaert, F.; MacCallum, D.; Mehmood, A.; Hamdouch, A. General introduction: The return of social innovation as a scientific concept and a social practice. In The International Handbook on Social Innovation: Collective Action, Social Learning and Transdisciplinary Research; Moulaert, F., MacCallum, D., Mehmood, A., Hamdouch, A., Eds.; Edward Elgar Publishing: London, UK, 2013; pp. 1-6. [CrossRef]

41. Scott, A.J. Cultural economy and the creative field of the city. Geogr. Ann. Ser. B Hum. Geogr. 2010, 92, 115-130. [CrossRef]

42. Bianchini, F.; Parkinson, M. Cultural Policy and Urban Regeneration: The West European Experience; Manchester University Press: Manchester, UK, 1993.

43. Evans, G.; Shaw, P. The Contribution of Culture to Regeneration in the UK: A Review of Evidence-A Report to the Department for Culture Media and Sport. 2004. Available online: http:/ /www.scholars-on-bilbao.info/fichas/EvansShaw2004.pdf (accessed on 20 September 2021).

44. García, M. Citizenship practices and urban governance in European cities. Urban Stud. 2006, 43, 745-765. [CrossRef]

45. Liu, Y.D. Event and sustainable culture-led regeneration: Lessons from the 2008 European Capital of Culture, Liverpool. Sustainability 2019, 11, 1869. [CrossRef] 
46. Evans, G. Measure for measure: Evaluating the evidence of culture's contribution to regeneration. Urban Stud. 2005, 42, 959-983. [CrossRef]

47. Demartini, P.; Marchegiani, L.; Marchiori, M.; Schiuma, G. Connecting the Dots: A Proposal to Frame the Debate Around Cultural Initiatives and Sustainable Development. In Cultural Initiatives for Sustainable Development; Springer International Publishing: Basel, Switzerland, 2021.

48. Duxbury, N.; Jeannotte, M.S. Making it real: Measures of culture in local sustainability planning and implementation in Making Culture Count. In New Directions in Cultural Policy Research; MacDowall, L., Badham, M., Blomkamp, E., Dunphy, K., Eds.; Palgrave Macmillan: London, UK, 2015; pp. 145-161.

49. Guzman, P.; Roders, A.P.; Colenbrander, B. Measuring links between cultural heritage management and sustainable urban development: An overview of global monitoring tools. Cities 2017, 60, 192-201. [CrossRef]

50. Sacco, P.L.; Blessi, G.T.; Nuccio, M. Cultural policies and local planning strategies: What is the role of culture in local sustainable development? J. Arts Manag. Law Soc. 2009, 39, 45-64. [CrossRef]

51. Evans, G. Creative cities, creative spaces, and urban policy. Urban Stud. 2009, 46, 1003-1040. [CrossRef]

52. European Union. European Union. European Agenda for Culture. In Communication from the Commission to the European Parliament, the Council, the European Economic, and Social Committee, and the Committee of the Regions; European Commission: Brussels, Belgium, 2007.

53. European Union. A New European Agenda for Culture. In Communication from the Commission to the European Parliament, the European Council, the Council, the European Economic, and Social Committee, and the Committee of the Regions; European Commission: Brussels, Belgium, 2018.

54. Markusen, A.; Gadwa, A. Arts and culture in urban or regional planning: A review and research agenda. J. Plan. Educ. Res. 2010, 29, 379-391. [CrossRef]

55. Benassi, F.; D’Elia, M.; Petrei, F. The "meso" dimension of territorial capital: Evidence from Italy. Reg. Sci. Policy Pract. 2021, 13, 159-175. [CrossRef]

56. Montalto, V.; Moura, C.J.T.; Langedijk, S.; Saisana, M. Culture counts: An empirical approach to measure the cultural and creative vitality of European cities. Cities 2019, 89, 167-185. [CrossRef]

57. Scott, A.J. The Cultural Economy of Cities: Essays on the Geography of Image-Producing Industries; Sage: London, UK, 2000.

58. Yin, M.; Derudder, B. Geographies of cultural industries across the global urban system. Geogr. Compass 2021, 15. [CrossRef]

59. Marrocu, E.; Paci, R. Education or creativity: What matters most for economic performance? Econ. Geogr. 2012, 88, 369-401. [CrossRef]

60. Lorenzen, M.; Frederiksen, L. Why do cultural industries cluster? Localization, urbanization, products and projects. In Creative Cities, Cultural Clusters and Local Economic Development; Cook, P., Lazzeretti, L., Eds.; Edward Elgar Publishing: Cheltenham, UK, 2008.

61. Nuccio, M.; Ponzini, D. What does a cultural district actually do? Critically reappraising 15 years of cultural district policy in Italy. Eur. Urban Reg. Stud. 2017, 24, 405-424. [CrossRef]

62. Burke, P. The Italian Renaissance: Culture and Society in Italy; Princeton University Press: Princeton, NJ, USA, 2014.

63. UN. World Population Prospects 2019. Available online: https:/ / population.un.org/wpp/ (accessed on 20 September 2021).

64. The World Bank. Urban Development. 2020. Available online: https://www.worldbank.org/en/topic/urbandevelopment/ overview\#1 (accessed on 20 September 2021).

65. Fainstein, S.S. The just city. Int. J. Urban Sci. 2014, 18, 1-18. [CrossRef]

66. KEA. Culture and Creative Sectors in the European Union-Key Future Developments, Challenges and Opportunities; Policy Department for Structural and Cohesion Policies on Behalf of the European Parliament Committee on Culture and Education; KEA: Brussels Belgium, 2019.

67. Bonet, L.; Donato, F. The financial crisis and its impact on the current models of governance and management of the cultural sector in Europe. ENCATC J. Cult. Manag. Policy 2011, 1, 4-11.

68. Bertoni, A.; Dubini, P.; Monti, A. Participatory event platforms in the urban context: The importance of stakeholders' meaning of "participation". In Cultural Initiatives for Sustainable Development Management, Participation and Entrepreneurship in the Cultural and Creative Sector; Contributions to Management Science Series; Demartini, P., Marchegiani, L., Marchiori, M., Schiuma, G., Eds.; Springer (Indexed in SCOPUS): Berlin/Heidelberg, Germany, 2021; pp. 271-292. ISBN 978-3-030-65686-7. [CrossRef]

69. Biondi, L.; Demartini, P.; Marchegiani, L.; Marchiori, M.; Piber, M. Understanding orchestrated participatory cultural initiatives: Mapping the dynamics of governance and participation. Cities 2020, 96, 102459. [CrossRef]

70. Lazzeretti, L.; Boix, R.; Capone, F. Do creative industries cluster? Mapping creative local production systems in Italy and Spain. Ind. Innov. 2008, 15, 549-567. [CrossRef]

71. UCCN. Special edition: Widening local development pathways. In Creative Economy Report; UCCN: Paris, France, 2013.

72. Miguel, B.S.; Herrero-Prieto, L.C. A Spatial-Temporal Analysis of Cultural and Creative Industries with Micro-Geographic Disaggregation. Sustainability 2020, 12, 6376. [CrossRef]

73. Czarniawska, B. A Tale of Three Cities; Oxford University Press: Oxford, UK, 2002

74. Accardo, G.; Giani, E.; Giovagnoli, A. The risk map of Italian cultural heritage. J. Archit. Conserv. 2003, 9, 41-57. [CrossRef]

75. Mariani, M.M. Coopetition as an emergent strategy: Empirical evidence from an Italian consortium of opera houses. Int. Stud. Manag. Organ. 2007, 37, 96-126. [CrossRef] 
76. Putnam, R.D. Making Democracy Work: Civic Traditions in Modern Italy; Princeton University Press: Princeton, NJ, USA, 1993.

77. Settis, S. Battaglie Senza Eroi: I Beni Culturali tra Istituzioni e Profitto Electa; Mondadori Electa: Milan, Italy, 2005.

78. Fratesi, U.; Perucca, G. Territorial capital and the resilience of European regions. Ann. Reg. Sci. 2018, 60, 241-264. [CrossRef]

79. Perucca, G. The role of territorial capital in local economic growth: Evidence from Italy. Eur. Plan. Stud. 2012, 22, 537-562. [CrossRef]

80. Lazzeretti, L.; Capone, F.; Seçilmiş, I.E. In search of a Mediterranean creativity. Cultural and creative industries in Italy, Spain and Turkey. Eur. Plan. Stud. 2016, 24, 568-588. [CrossRef]

81. Kemeny, T.; Nathan, M.; O'Brien, D. Creative differences? Measuring creative economy employment in the United States and the UK. Reg. Stud. 2019, 54, 377-387. [CrossRef]

82. European Commission. Promoting Cultural and Creative Sectors for Growth and Jobs in the EU COM(2012) 537 Final. 2012. Available online: https:/ / eur-lex.europa.eu/legal-content/EN/TXT/PDF/?uri=CELEX:52012DC0537\&from=EN (accessed on 20 September 2021).

83. Pratt, A.C. Creative Clusters: Towards the Governance of the Creative Industries Production System? Media Int. Aust. 2004, 112, 50-66. [CrossRef]

84. Oppio, A.; Bottero, M.; Ferretti, V.; Fratesi, U. Giving space to multicriteria analysis for cmplex cultural heritage systems: The case of the castles in Valle d'Aosta region. J. Cult. Herit. 2015, 16, 779-789. [CrossRef]

85. Montalto, V.; Moura, C.J.T.; Langedijk, S.; Saisana, M. The Cultural and Creative Cities Monitor; European Commission: Brussels, Belgium, 2017. [CrossRef]

86. JRC-OECD. Handbook on constructing composite indicators. In Methodology and User Guide; Nardo, M., Saisana, M., Saltelli, A., Tarantola, S., Hoffman, A., Giovannini, E., Eds.; OECD Publishing: Paris, France, 2008; ISBN 978-92-64-04345-9.

87. Camerin, F. Open Issues and Opportunities to Guarantee the "Right to the 'Healthy' City" in the Post-Covid-19 European City. Contesti. Città. Territori. 2021, 2, 149-162.

88. Moreno, C.; Allam, Z.; Chabaud, D.; Gall, C.; Pratlong, F. Introducing the "15-Minute City": Sustainability, Resilience and Place Identity in Future Post-Pandemic Cities. Smart Cities 2021, 4, 93-111. [CrossRef]

89. Pozoukidou, G.; Chatziyiannaki, Z. 15-Minute City: Decomposing the New Urban Planning Eutopia. Sustainability 2021, 13, 928. [CrossRef]

90. Della Lucia, M.; Segre, G. Intersectoral local development in Italy: The cultural, creative and tourism industries. Int. J. Cult. Tour. Hosp. Res. 2017, 11, 450-462. [CrossRef]

91. Jansson, J.; Power, D. Fashioning a global city: Global city brand channels in the fashion and design industries. Reg. Stud. 2010, 44, 889-904. [CrossRef]

92. Cartone, A.; Panzera, D. Deprivation at local level: Practical problems and policy implications for the province of Milan. Reg. Sci. Policy Pr. 2021, 13, 43-61. [CrossRef]

93. Dubini, P. L'infrastruttura Culturale di Milano in AA.VV. Città, Quartieri, reti e Cultura a Milano Che Fare Disponibile su. 2019. Available online: https:/ / www.che-fare.com/progetto/milano-city-school-un-dossier-sulle-trasformazioni-culturali-delterritorio-milanese/ (accessed on 20 September 2021).

94. Foster, S.R.; Iaione, C. The city as a commons. Yale Law Poly Rev. 2015, 34, 281. [CrossRef]

95. Bertoni, A. Il valore della cultura nella città dei 15 minuti. Economia \& management; SDA Bocconi: Milan, Italy, $2021 ;$ pp. 69-72.

96. Soini, K.; Dessein, J. Culture-sustainability relation: Towards a conceptual framework. Sustainability 2016, 8, 167. [CrossRef]

97. Ferilli, G.; Sacco, P.L.; Noda, K. Culture driven policies and revaluation of local cultural assets: A tale of two cities, Otaru and Yūbari. City Cult. Soc. 2015, 6, 135-143. [CrossRef]

98. Ghasemi, K.; Hamzenejad, M.; Meshkini, A. An analysis of the spatial distribution pattern of social-cultural services and their equitable physical organization using the TOPSIS technique: The case-study of Tehran, Iran. Sustain. Cities Soc. 2019, $51,101708$. [CrossRef] 